\title{
Engineering geology of Waterside Green, Sydney, Australia
}

\author{
*Indra Jworchan, Tony O’Brien, Emged Rizkalla, and Paul Gorman \\ Geotechnique Pty Ltd \\ Lemko Place, Penrith, Sydney, Australia \\ (*Email: indra.jworchan@geotech.com.au)
}

\begin{abstract}
Development of low-lying land affected by high water table in saline and sodic soils and local swampy areas remains a challenge for the local government, developers, and other regulators. The development control plan for a proposed residential or commercial subdivision in such a site in Penrith, Sydney, Australia, states that the drainage and stormwater management systems within and across the site should be improved and proposed buildings should be constructed on the ground higher than the 100-year flood level. This paper presents the results of engineering geological and geotechnical investigations for the proposed subdivision. The subsurface profile at the site comprises alluvial deposits underlain by residual soil, which in turn is underlain by shale and sandstone. In the eastern portion of the site, the alluvial deposits comprise a sequence of clay, sand and gravel, and in the western portion they contain a succession of clean sand and gravel. The alluvium in the eastern portion of the site is saline whereas it is generally non-saline in the western portion. All saline soils are sodic and most nonsaline ones are non-sodic. This paper discusses the suitability of on-site soils for use in a structural fill and impermeable clay liner as well as the management of saline and dispersive soils.
\end{abstract}

\section{INTRODUCTION}

Engineering geological and geotechnical investigations were carried out at a proposed residential and commercial subdivision, known as the Waterside Green Development, located in Penrith, Sydney, Australia. The proposed development comprises (Fig. 1) a commercial area consisting of two- to four-storey commercial buildings and office blocks (16 ha), a residential area comprising 700 future dwellings and internal roads ( $40 \mathrm{ha})$, and five lakes and several laterals (17 ha).

The Development Control Plan (Penrith City Council 2004) for the proposed subdivision states that the drainage and stormwater management system within and across the site should be improved and that future dwellings and other structures should be constructed on the ground higher than the 1 in 100-year flood level, without the necessity of importing fill material. The subdivision master plan proposes the excavation of a series of lakes and laterals to improve drainage, implementation of a stormwater management system, and use of materials gained from the excavation to raise site levels above the 1 in 100-year flood level.

Site works are estimated to involve the movement of approximately $570,000 \mathrm{~m}$ of site material and possible importation of approximately $75,000 \mathrm{~m}$ of clay for lining the lakes and laterals.

This paper describes the following:

- Surface and subsurface site conditions.
- Groundwater conditions, including depths to groundwater levels and their variations.

- Results of laboratory tests on soils and bedrock in terms of physical, engineering, and chemical properties.

- Assessment of the suitability of excavated materials for use as general structural fill and as impermeable clay liner in lakes and laterals.

- Recommended soil management plan.

The site is located at the corner of Cranebrook and Andrews Roads, Penrith, about $50 \mathrm{~km}$ west of Sydney, and is approximately $73 \mathrm{ha}$ in area. The general topography of the site is gently undulating with an overall slope of less than $4 \%$, dipping due west and north. The ground surface elevation across the site varies from about Reference Level (RL) 22.0 to about $25.0 \mathrm{~m}$ of Australian Height Datum (AHD). The poor natural drainage (flowing essentially due north and west) is responsible for runoff accumulation and formation of swamps in some places.

\section{REGIONAL GEOLOGY}

The geological map of Penrith (Scale 1: 100,000) indicates that the site is underlain by the Wianamatta Group of shales of Middle Triassic age, consisting of shale, carbonaceous claystone, laminite, and sandstone. The shale is overlain by alluvial deposits consisting of gravel, sand, silt, and clay of variable thicknesses (Jones and Clark 1987). The soil landscape map of Penrith (Scale 1:100,000) indicates that the site lies on the Quaternary terrace of the nearby Nepean 


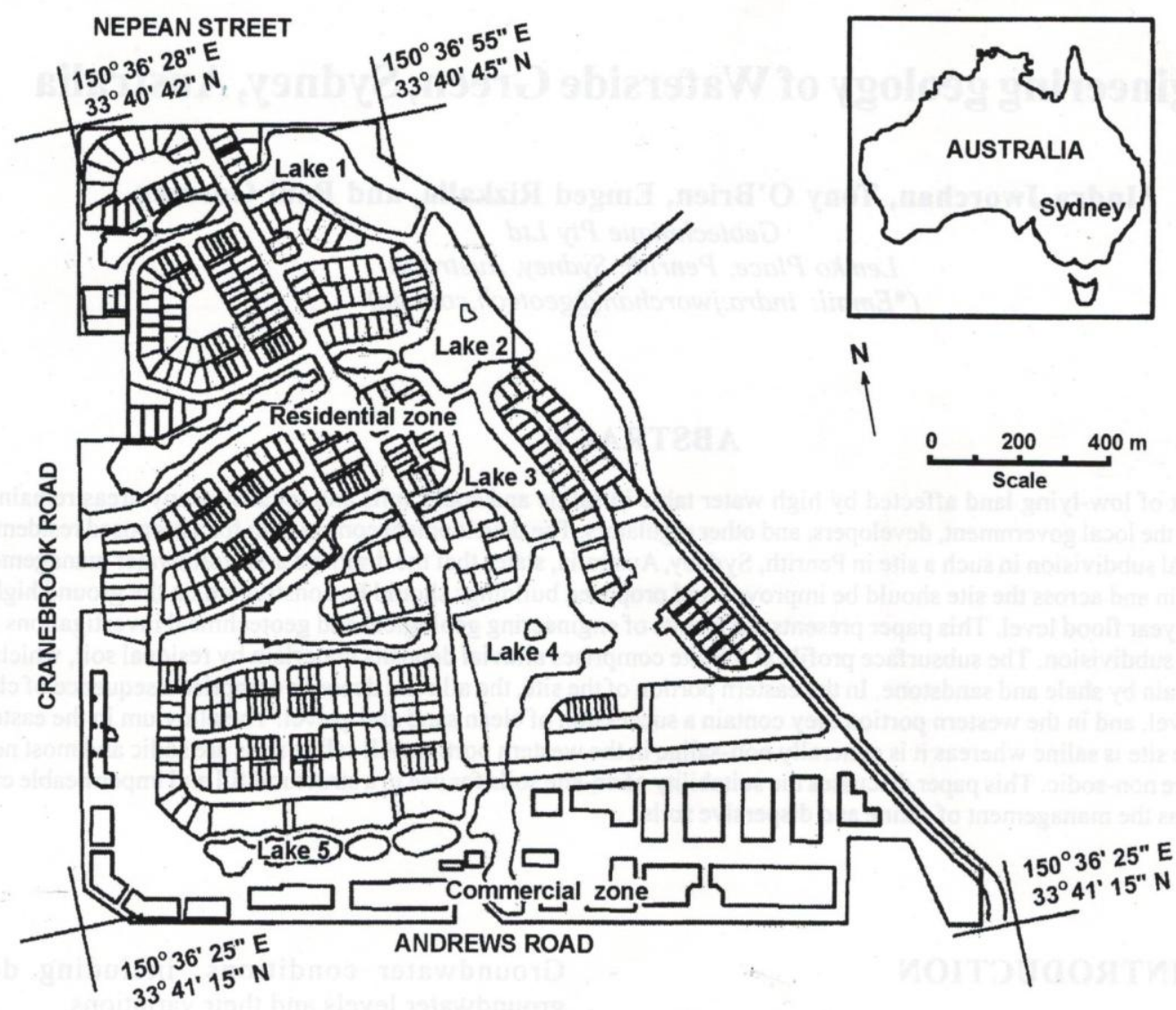

Fig. 1: Proposed development plan

River. The local relief at the site is less than $3.0 \mathrm{~m}$ with general ground slopes of about $2 \%$. The soil is poorly structured clay and sand, with possible ironstone nodules (Bannerman and Hazelton 1990).

Department of Land and Water Conservation NSW (2002) classified the soils in the site into the sandy soil group (SSG), clayey soil group (CSG), and duplex soil group (DSG).

\section{SUBSURFACE PROFILES}

The engineering geological and geotechnical investigations were carried out by drilling 39 boreholes and excavating more than 100 test pits (Geotechnique 2003). The test pits were evenly distributed across the site. Ten boreholes were extended to the bedrock at depths of 14.0 to $20.0 \mathrm{~m}$ and the remaining boreholes were terminated at varying depths in the gravel bed. Most test pits were terminated in alluvial sand or clay, at depths of about $3.0 \mathrm{~m}$ from the existing ground surface. Six of the test pits were terminated in the gravel bed at depths of 2.0 to $3.0 \mathrm{~m}$. Fig. 2 depicts the approximate locations of boreholes and test pits from which samples were recovered for laboratory testing.

Based on the sequence of alluvial deposits encountered in test pits and boreholes, the subsurface profiles across the site are generally assessed to be of two types: the clayey profile, including the CSG and DSG, and the sandy profile comprising the SSG. The approximate boundary between the two types of subsurface profile is shown in Fig. 2 (plan) and Fig. 3 and Fig. 4 (sections) and detailed in Table 1.

The sandy profile covers about $65 \%$ of the area. A thin layer of residual clay was encountered over the bedrock in some boreholes drilled within the clayey profile. The clay, sand, and gravel listed in Table 1 are alluvial deposits. In general, the gravel bed is thicker in the sandy profile. The thickness of clay in most portions of the site with a clayey profile varies from about $5.0 \mathrm{~m}$ to $10.0 \mathrm{~m}$. The clay is about $5.0 \mathrm{~m}$ to $7.0 \mathrm{~m}$ in the mid portion and thicker, about $8.0 \mathrm{~m}$ to $10.0 \mathrm{~m}$, in the northern and southern portions of the clayey profile. Alluvium is underlain by shale, which in turn is underlain by sandstone.

\section{GROUNDWATER CONDITIONS}

Eight standpipes and (or) monitoring wells were installed across the site (Geotechnique 2003). The results of groundwater monitoring (Table 2) indicate that the depths to groundwater levels within the clayey profile (BH204, $\mathrm{BH} 207$, and $\mathrm{BH} 223$ ) range from 3.6 to $5.9 \mathrm{~m}$, with approximate elevations in the order of RL 19.0 to $20.0 \mathrm{~m} \mathrm{AHD}$. In the areas with a sandy profile (BH209, BH2IO, BH219, BH226, and $\mathrm{BH} 227)$, the depths to groundwater levels range from 3.0 to 
Table 1: Types of subsurface profiles

\begin{tabular}{l|c}
\hline \multicolumn{2}{c}{ Clayey profile (Eastern part) } \\
\hline Soil unit & $\begin{array}{l}\text { Depth to top } \\
\text { of unit }(\mathbf{m})\end{array}$ \\
\hline Topsoil & 0.0 \\
\hline Clay & $0.1-0.3$ \\
\hline Sand & $2.5-10.5$ \\
\hline Gravel & $4.0-12.5$ \\
\hline Bedrock & $8.0-18.0$ \\
\hline Sandy profile (Western side) \\
\hline Soil unit & $\begin{array}{l}\text { Depth to top } \\
\text { of unit (m) }\end{array}$ \\
\hline Topsoil & 0.0 \\
\hline Sand & $0.1-0.3$ \\
\hline Gravel & $2.0-5.4$ \\
\hline Bedrock & $11.0-16.0$ \\
\hline
\end{tabular}

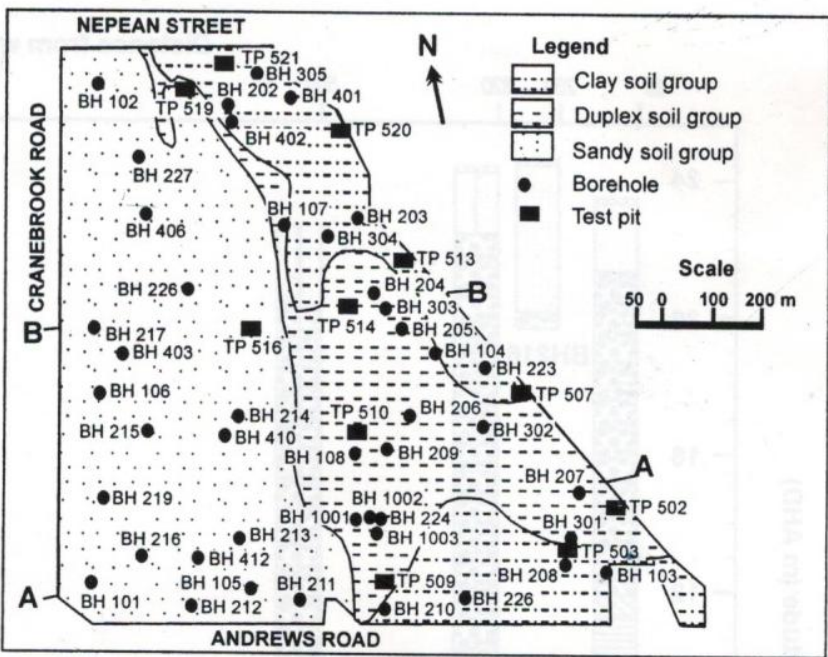

Fig. 2: Types of subsurface profiles. Section lines A-A and $\mathrm{B}-\mathrm{B}$ are also indicated.

Table 2: Depth to groundwater levels on various dates

\begin{tabular}{l|c|c|c|c|c|c|c|c}
\hline Subsurface profile & \multicolumn{3}{|c|}{ Clayey profile } & \multicolumn{5}{c}{ Sandy profile } \\
\hline \multicolumn{1}{c|}{ Borehole } & BH204 & BH2O7 & BH223 & BH209 & BH210 & BH219 & BH226 & BH227 \\
\hline $\begin{array}{c}\text { Date/Ground surface } \\
\text { RL (m AHD) }\end{array}$ & $\mathbf{2 2 . 7 0}$ & $\mathbf{2 5 . 2 0}$ & $\mathbf{2 4 . 0 0}$ & $\mathbf{2 4 . 6 0}$ & $\mathbf{2 5 . 2 0}$ & $\mathbf{2 3 . 1 0}$ & $\mathbf{2 2 . 5 0}$ & $\mathbf{2 2 . 2 0}$ \\
\hline 9 August 1999 & \multicolumn{3}{|c|}{ Not measured } & 4.48 & 4.50 & 3.11 & 3.57 & 3.81 \\
\hline 11 August 1999 & \multicolumn{3}{|c|}{ Not measured } & 4.50 & 4.65 & 3.11 & 3.57 & 3.84 \\
\hline 13 August 1999 & 3.80 & 5.85 & 4.87 & 4.49 & 4.66 & 3.11 & 3.56 & 3.81 \\
\hline 16 August 1999 & 3.79 & 5.85 & 4.87 & 4.50 & 4.65 & 3.11 & 3.55 & 3.84 \\
\hline 18 August 1999 & 3.80 & 5.75 & 4.85 & 4.45 & 4.60 & 3.10 & 3.50 & 3.75 \\
\hline 20 August 1999 & 3.67 & 5.80 & 4.83 & 4.47 & 4.62 & 3.09 & 3.50 & 3.80 \\
\hline 24 August 1999 & 3.73 & 5.87 & 4.89 & 4.50 & 4.67 & 3.12 & 3.50 & 3.83 \\
\hline 2 September 1999 & 3.73 & 5.87 & 4.88 & 4.52 & 4.69 & 3.14 & 3.51 & 3.85 \\
\hline 1 October 1999 & 3.82 & 5.90 & 4.88 & 4.50 & 4.65 & 3.14 & 3.50 & 3.82 \\
\hline 1 November 1999 & 3.69 & 5.77 & 4.80 & 4.40 & 4.50 & 3.04 & 3.40 & 3.80 \\
\hline 28 June 2001 & 3.80 & 5.29 & Not measured & 4.77 & 3.12 & Not measured \\
\hline
\end{tabular}

$4.7 \mathrm{~m}$ with approximate elevations in the order of RL 18.5 to $20.5 \mathrm{mAHD}$.

Table 2 also indicates that depths to groundwater levels vary considerably from place to place. This is due to the fact that groundwater levels are influenced by many factors, including topography, hydrogeology, subsoil permeability, drainage conditions, and climatic conditions. However, the groundwater levels in each monitored standpipe and (or) well did not vary significantly with time.

\section{FIELD PERMEABILITY TEST}

Permeability tests were carried out in standpipe piezometers and groundwater-monitoring wells to estimate the permeability of the gravel bed, using falling head and rising head methods. The falling head (Coffey Geosciences 1999) and rising head (Robert Carr and Associates 2003) permeability tests in four boreholes indicated the permeability of the gravel bed in the range of $2.0 \times 10^{-7}$ to 2.0 $\mathrm{x} 10^{-4}$ and $7.9 \times 10^{-7}$ to $2.5 \times 10^{-5} \mathrm{~m} / \mathrm{sec}$, respectively. The lower and variable permeability values are probably due to cementation in the gravel bed.

A 48-hour pumping test was also carried out to assess field permeability. The test involved pumping groundwater out at a rate of $60 \mathrm{~m}^{3} /$ day from a centrally located well constructed in Lake 2 (Fig. 1) and monitoring groundwater levels in three wells located at distances of 2.0,10.0, and 15.0 $\mathrm{m}$ from the test well. The geometrical mean of the permeability values estimated from the pumping tests is estimated at $5.0 \mathrm{x}$ $10^{-4} \mathrm{~m} / \mathrm{sec}$ (Robert Carr and Associates 2003). It should be noted that the permeability values of alluvial gravel estimated using falling and rising head methods are lower than those estimated from the pumping test.

\section{LABORATORY TEST RESULTS}

The alluvial soil samples were tested to determine their geotechnical properties including strength and 


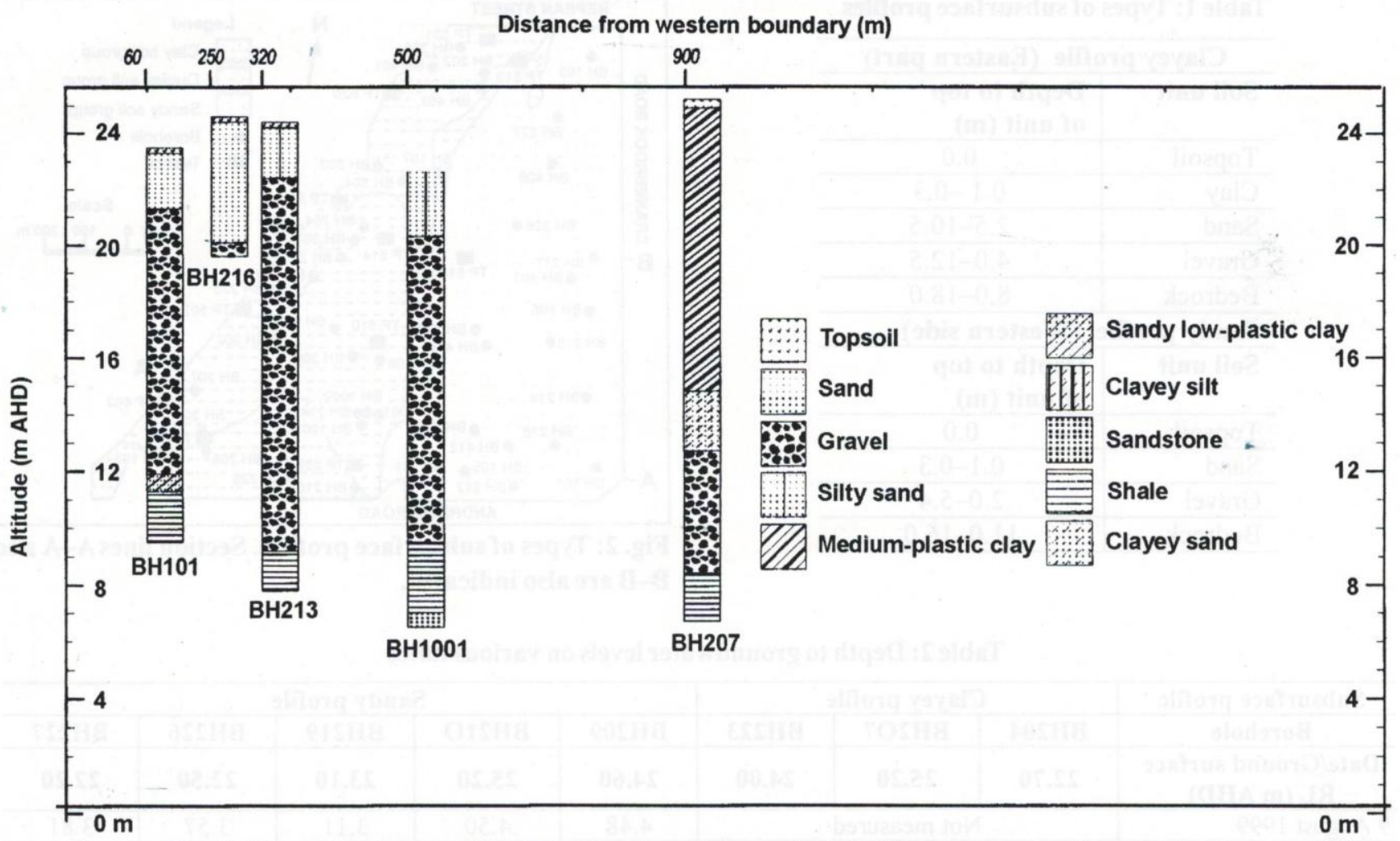

Fig. 3: Cross-section A-A (see Fig. 2), subsurface profiles in the southern portion of the site

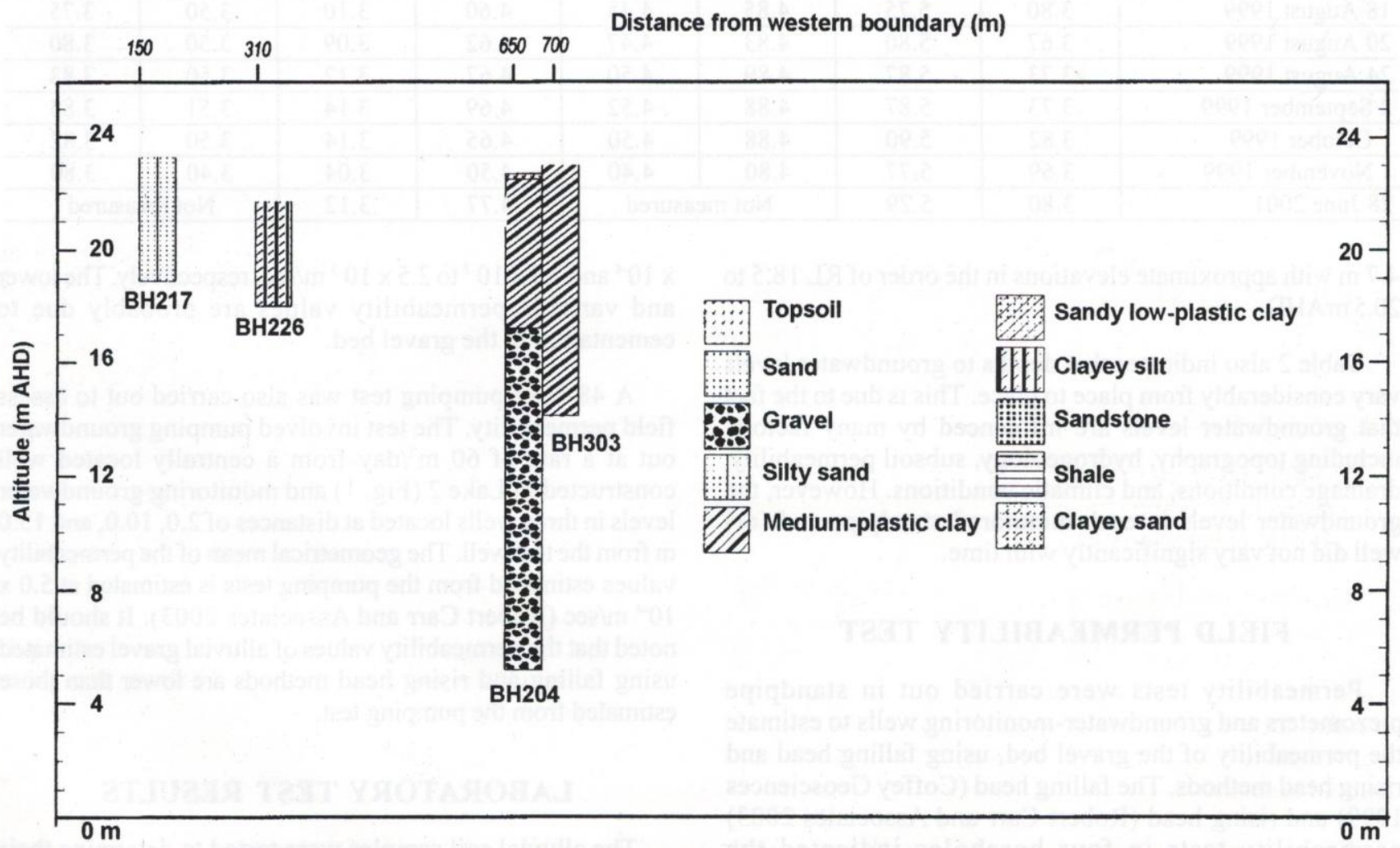

Fig. 4: Cross-section B-B (see Fig. 2), subsurface profiles in the northern portion of the site 
Table 3: Summary of basic soil tests

\begin{tabular}{l|c|c|c|c|c|c}
\hline \multirow{2}{*}{ Soil properties } & \multicolumn{2}{|c|}{ Alluvial soils from clayey profile } & \multicolumn{3}{c}{ Alluvial soils from sandy profile } \\
\cline { 2 - 7 } & Maximum & Minimum & Mean & Maximum & Minimum & Mean \\
\hline Moisture content (\%) & 31.5 & 9.0 & 20.5 & 16.5 & 6.5 & 10.5 \\
\hline Liquid Limit (\%) & 59 & 26 & 48.5 & 18 & 15 & 16.5 \\
\hline \multicolumn{1}{c}{ Plastic Limit (\%) } & 20 & 11 & 17.0 & 15 & 12 & 13.5 \\
\hline Plasticity Index (\%) & 40 & 15 & 32.0 & 5 & 0 & 3.0 \\
\hline Linear Shrinkage (\%) & 17 & 8 & 14.5 & 3 & 0.5 & 2.5 \\
\hline Maximum Dry Density (t/m $\left.{ }^{3}\right)$ & 2.19 & 1.50 & 17.7 & 2.04 & 1.92 & 1.98 \\
\hline Optimum Moisture Content (\%) & 24 & 9 & 16.5 & 12 & 8.5 & 10.5 \\
\hline California Bearing Ratio (\%) & 8 & 3 & 5.0 & 50 & 8 & 25.0 \\
\hline Emerson Class & Class 1 & Class 2 & - & Class 5 & Class 5 & - \\
\hline Shrink/ Swell Index (\%) & 4.1 & 0.7 & 2.5 & 0.9 & 0.4 & 0.7 \\
\hline Pinhole dispersibility class & PD2 & ND1 & - & D2 & PD2 & - \\
\hline Permeability $\left(10^{-9} \mathrm{~m} / \mathrm{s}\right)$ & 1.2 & 0.6 & 0.9 & 54.2 & 1.7 & 17.7 \\
\hline Insitu wet density $\left(\mathrm{t} / \mathrm{m}^{3}\right)$ & 2.15 & 1.93 & 2.09 & 2.18 & 1.67 & 2.06 \\
\hline Insitu Dry Density $\left(\mathrm{t} / \mathrm{m}^{3}\right)$ & 1.84 & 1.54 & 1.62 & 1.97 & 1.54 & 1.86 \\
\hline
\end{tabular}

Table 4: Summary of shear strength and consolidation tests on alluvial clay

\begin{tabular}{l|c|c|c|c|c|c|c}
\hline Borehole & Depth (m) & $\begin{array}{c}\text { Moisture } \\
\text { content }(\%)\end{array}$ & $\begin{array}{c}\text { Dry density } \\
\left(\mathrm{t} / \mathrm{m}^{3}\right)\end{array}$ & $\begin{array}{c}\text { Undrained } \\
\text { cohesion } \\
(\mathrm{kPa})\end{array}$ & $\begin{array}{c}\text { Initial } \\
\text { void ratio }\end{array}$ & $\begin{array}{c}\text { Compression } \\
\text { index }\end{array}$ & $\begin{array}{c}\text { Coefficient of } \\
\text { consolidation* } \\
\left(\mathrm{m}^{2} / \text { year }\right)\end{array}$ \\
\hline $\mathrm{BH} 301$ & $1.0-1.5$ & 22.6 & 1.69 & 1.78 & 0.713 & 0.125 & 5.66 \\
\hline $\mathrm{BH} 301$ & $2.5-3.0$ & 24.2 & 1.66 & 152 & 0.680 & 0.082 & 6.15 \\
\hline $\mathrm{BH} 302$ & $5.5-6.0$ & 26.9 & 1.55 & Not Tested & 0.709 & 0.122 & 12.33 \\
\hline $\mathrm{BH} 303$ & $1.0-1.5$ & 21.9 & 1.72 & 197 & 0.633 & 0.123 & 1.09 \\
\hline $\mathrm{BH} 303$ & $2.5-3.0$ & 18.7 & 1.76 & 239 & 0.558 & 0.115 & 1.30 \\
\hline $\mathrm{BH} 305$ & $5.0-5.5$ & 24.3 & 1.66 & 110 & 0.650 & 0.108 & 2.56 \\
\hline $\mathrm{BH} 305$ & $1.0-1.5$ & 21.9 & 1.95 & 338 & 0.569 & 0.089 & 2.76 \\
\hline $\mathrm{BH} 305$ & $2.5-3.0$ & 12.5 & 2.00 & 173 & 0.448 & 0.072 & 5.78 \\
\hline
\end{tabular}

${ }^{*}$ Coefficient of consolidation (Cu) for pressure range of 100 to $200 \mathrm{kPa}$

consolidation characteristics. Based on the results of tests on ten to thirty samples, the basic soil properties for clayey and sandy alluvium are summarised in Table 3 . The permeability tests were carried out on remoulded soil samples compacted (standard compaction at about optimum moisture content) to a dry density ratio of $100 \%$.

The alluvial clayey soil samples from the clayey profile were tested to determine their undrained shear strength and consolidation characteristics (Table 4).

The topsoil and alluvium were also tested to determine their chemical properties (Tables 5 and 6). The topsoil samples were tested to assess their ability to support lawn growth and determine if further treatments would be required to make them suitable for this purpose. The alluvial soils were tested to assess their salinity and sodicity as well as to ascertain their distribution across the site.

Samples designated Lot 1 to Lot 10 were prepared by mixing several topsoil samples collected from an area of similar visual appearance. Therefore, they represent an average value for an area with similar topsoil characteristics.

The recovered rock cores from the boreholes were tested for the determination of point-load strength index (I 50) at regular depth intervals. The bedrock encountered within the borehole termination depths was assessed to be of medium to high strength (Australian Standard 1993).

\section{PROPERTIES OF TOPSOIL}

The topsoil predominantly comprises silt and sandy silt with clayey silt at some locations. The silt is potentially dispersive, whereas the clayey topsoil is non-dispersive. As the coverage of clayey silt is limited, unless selective stripping is carried out, most of the topsoil is assessed to be susceptible to erosion and piping.

The residential and commercial areas will require about 300 and $100 \mathrm{~mm}$ thick topsoil respectively for lawn and 
Table 5: Summary of chemical tests on topsoil

\begin{tabular}{l|c|c|c|c|c|c}
\hline $\begin{array}{l}\text { Sample } \\
\text { No. }\end{array}$ & Depth (m) & $\mathbf{p H}$ & $\begin{array}{l}\text { Electrical } \\
\text { conductivity } \\
(\mathbf{m S / c m})\end{array}$ & $\begin{array}{l}\text { Exchangeable } \\
\text { sodium (meq \%) }\end{array}$ & $\begin{array}{l}\text { Cation Exchange } \\
\text { Capacity (meq \%) }\end{array}$ & $\begin{array}{l}\text { Phosphate } \\
(\mathbf{m g} / \mathbf{k g})\end{array}$ \\
\hline Lot1 & $0.0-0.30$ & 5.3 & 0.06 & 0.06 & 2.71 & Not tested \\
\hline Lot2 & $0.0-0.30$ & 5.4 & 0.07 & 0.05 & 3.98 & 28.2 \\
\hline Lot3 & $0.0-0.30$ & 5.5 & 0.09 & 0.07 & 3.30 & 11.9 \\
\hline Lot4 & $0.0-0.30$ & 6.0 & 0.06 & 0.06 & 3.69 & 4.3 \\
\hline Lot5 & $0.0-0.30$ & 5.3 & 0.09 & 0.07 & 2.37 & 20.6 \\
\hline Lot6 & $0.0-0.30$ & 5.5 & 0.08 & 0.20 & 5.21 & $<0.8$ \\
\hline Lot7 & $0.0-0.30$ & 5.4 & 0.13 & 0.32 & 9.07 & $<0.8$ \\
\hline Lot8 & $0.0-0.30$ & 5.4 & 0.05 & 0.13 & 4.90 & $<0.8$ \\
\hline Lot9 & $0.0-0.30$ & 5.2 & 0.11 & 0.25 & 12.15 & $<0.8$ \\
\hline Lot10 & $0.0-0.30$ & 5.6 & 0.07 & 0.31 & 9.77 & $<0.8$ \\
\hline BH412 & $0.0-0.30$ & 5.4 & 0.05 & 0.06 & 2.35 & 1.1 \\
\hline BH410 & $0.0-0.30$ & 4.8 & 0.17 & 0.04 & 2.31 & 3.3 \\
\hline BH406 & $0.0-0.30$ & 6.0 & 0.07 & 0.05 & 3.52 & 5.4 \\
\hline TP502 & $0.0-0.30$ & 5.6 & 0.06 & 0.20 & 7.28 & $<0.8$ \\
\hline TP513 & $0.0-0.30$ & 5.5 & 0.09 & 0.38 & 13.66 & $<0.8$ \\
\hline
\end{tabular}

gardening purposes. The topsoil is generally reasonably well balanced for turf growth but suffers from slight acidity, slight calcium deficiency, and low major nutrient (especially phosphorous) levels. The topsoil, as it exists, is not ideal for heavy-wear turf (such as playing fields) but is considered adequate for backyard turf (Sydney Environmental and Soils Laboratory 2003). To enhance the performance and improve the quality of topsoil, the following is recommended.

- Since the subsoils are calcium-deficient, it is recommended to spread gypsum at a rate of $300 \mathrm{~g} / \mathrm{m}^{2}$ on them.

- It is necessary to raise the $\mathrm{pH}$ to within a more appropriate range and improve the $\mathrm{Ca}: \mathrm{Mg}$ ratio by applying lime at a rate of $5 \mathrm{~kg} / \mathrm{m}^{3}$.

- It is needed to improve their nutrient levels by applying $20 \%$ of composted green waste and high-nitrogen turf starter.

\section{PROPERTIES OF ALLUVIAL SOILS}

The various alluvial soils across the site and their properties are the following.

Clayey alluvium has medium to high plasticity with potential for shrink or swell and slaking. It is dispersive to non-dispersive, practically impermeable, firm to stiff, and has low strength with California Bearing Ratio (CBR) values in the range of 3 to $5 \%$.

Sandy alluvium is fine-grained, potentially dispersive, and moderately to highly permeability. The soil is loose to dense with higher CBR values in the range of 5 to $10 \%$.
Alluvial gravel is fine- to coarse-grained, rounded, dense to very dense, variably cemented, and exhibits variable permeability values.

\section{Soil salinity}

Soil salinity is related to its salt content, which usually involves sodium chloride, but other salts also occur in some soils. The three main sources of salt are: (1) salts transported from the ocean and deposited by rainfall, (2) salts released during the process of soil and rock weathering, and (3) salts naturally present in the soil profile, resulting from marine sediments deposited in earlier geological times.

Soils are classified as saline if the electrical conductivity (ECe) of their saturated extracts exceeds $4 \mathrm{mS} / \mathrm{cm}$ (Taylor 1993). The results of electrical conductivity tests on subsoil samples (Table 6) indicate the following.

- The soils from the western portion of the site (sandy profile) are generally non saline.

- The soils from the eastern portion of the site (clayey profile) are generally slightly to highly saline. However, an exception was noted in the central portion of the clayey profile, where subsurface soils to a depth of about $1.5 \mathrm{~m}$ were non saline but were underlain by saline soils.

The approximate boundaries between saline and nonsaline soils are indicated in Fig. 2.

\section{Aggressivity}

Acidity, chloride content, resistivity, and sulphate content determine the aggressivity of subsurface soils and groundwater to steel or iron and concrete. Based on the laboratory test results and site conditions, the soils across the site were assessed to be non-aggressive to mildly 
Engineering geology of Waterside Green, Australia

Table 6: Summary of chemical tests on alluvial soils

\begin{tabular}{|c|c|c|c|c|c|c|c|c|}
\hline $\begin{array}{l}\text { Sample } \\
\text { location }\end{array}$ & $\begin{array}{l}\text { Depth } \\
\text { (m) }\end{array}$ & $\mathrm{pH}$ & $\begin{array}{c}\text { Electric } \\
\text { conductivity } \\
(\mathrm{mS} / \mathrm{cm})\end{array}$ & \begin{tabular}{|c|}
$\begin{array}{c}\text { Exchangeable } \\
\text { sodium } \\
\text { (meq \%) }\end{array}$ \\
\end{tabular} & $\begin{array}{c}\text { Cation exchange } \\
\text { capacity } \\
(\text { meq \%) }\end{array}$ & $\begin{array}{l}\text { Sulphate } \\
(\mathrm{mg} / \mathrm{kg})\end{array}$ & $\begin{array}{l}\text { Chloride } \\
(\mathrm{mg} / \mathrm{kg})\end{array}$ & $\begin{array}{l}\text { Resistivity } \\
\text { (ohms.m) }\end{array}$ \\
\hline TP503 & $0.3-1.4$ & 7.5 & 2.11 & 7.58 & 25.89 & 280 & 1340 & 1.88 \\
\hline TP503 & $1.4-2.6$ & 6.6 & 3.08 & 6.57 & 23.62 & \multicolumn{3}{|c|}{ Not tested } \\
\hline ТР507 & $0.3-1.3$ & 6.1 & 0.04 & 0.16 & 4.67 & 190 & 120 & 100.98 \\
\hline TP507 & $1.3-1.6$ & 5.6 & 0.12 & 0.67 & 11.50 & 120 & 30 & 38.06 \\
\hline TP507 & $1.8-2.7$ & 6.3 & 0.25 & 2.44 & 12.72 & \multicolumn{3}{|c|}{ Not tested } \\
\hline ТР509 & $0.5-0.8$ & 5.1 & 0.11 & 0.34 & 3.82 & 70 & 30 & 71.67 \\
\hline TP509 & $1.9-2.2$ & 5.6 & 0.13 & 1.31 & 5.68 & \multicolumn{3}{|c|}{ Not tested } \\
\hline TP5IO & $0.5-0.7$ & 6.3 & 0.05 & 0.04 & 1.77 & 280 & 60 & 160.52 \\
\hline TP513 & $0.9-1.6$ & 4.9 & 2.27 & 4.82 & 22.47 & 290 & 1580 & 2.13 \\
\hline TP513 & $2.0-2.9$ & 6.3 & 2.72 & 5.02 & 21.33 & \multicolumn{3}{|c|}{ Not tested } \\
\hline TP514 & $0.4-0.9$ & 5.8 & 0.07 & 0.34 & 2.47 & 350 & 90 & I 72.72 \\
\hline TP514 & $1.1-1.7$ & 8.2 & 0.67 & 2.54 & 6.20 & \multicolumn{3}{|c|}{ Not tested } \\
\hline TP516 & $0.3-0.8$ & 5.4 & 0.05 & 0.06 & 2.58 & \multicolumn{3}{|c|}{ Not tested } \\
\hline TP516 & $1.0-1.6$ & 5.8 & 0.04 & 0.07 & 2.29 & $<5.0$ & 20 & 159.76 \\
\hline TP516 & $2.3-2.8$ & 6.1 & 0.03 & 0.06 & 1.84 & \multicolumn{3}{|c|}{ Not tested } \\
\hline TP519 & $0.5-1.0$ & 6.8 & 0.26 & 1.11 & 12.49 & 540 & 160 & 91.18 \\
\hline TP519 & $1.4-1.9$ & 7.9 & 0.28 & 1.08 & 6.81 & 740 & 190 & 15.07 \\
\hline TP520 & $0.8-1.7$ & 8.2 & 1.92 & 4.35 & 36.56 & 90 & 1060 & 1.8312 \\
\hline ТP520 & $2.1-2.9$ & 8.2 & 2.48 & 3.77 & 28.50 & \multicolumn{3}{|c|}{ Not tested } \\
\hline TP521 & $0.4-1.1$ & 8.6 & 1.69 & 4.74 & 23.22 & 250 & 1730 & 2.53 \\
\hline TP521 & $1.7-2.6$ & 8.4 & 2.78 & 4.15 & 25.31 & \multicolumn{3}{|c|}{ Not tested } \\
\hline BH401 & $1.1-1.6$ & 8.5 & 2.03 & 4.25 & 24.55 & Not tested & & \\
\hline BH401 & $2.5-2.9$ & 8.7 & 1.51 & 5.00 & 24.9 & Not tested & & \\
\hline BH1001 & $1.0-2.0$ & 6.2 & 0.05 & 0.80 & 2.52 & 10 & 20 & 101.70 \\
\hline BH1003 & $0.3-1.0$ & 6.4 & 0.06 & 0.70 & 3.11 & 10 & $<7$ & 107.80 \\
\hline
\end{tabular}

aggressive towards both iron or steel and concrete (Australian Standard 1995).

\section{Soil sodicity}

Sodicity is the level of exchangeable sodium in soils and is generally assessed by measuring total dissolved salts, exchangeable sodium percentage (ESP), and sodium adsorption ratio (SAR) (Taylor 1993). Sodic soils are prone to shrink or swell, very severe surface crusting, very low infiltration and hydraulic conductivity, very hard and dense subsurface layer formation, and severe gully and tunnel erosion. They restrict root growth and lead to shallow rooting depths for plants. Twenty-eight soil samples were tested to determine their sodicity and nineteen samples were assessed to be sodic to highly sodic. Most soil samples were recovered from the clayey profile. All saline soils were assessed to be sodic and most non-saline soils were assessed to be nonsodic. However, sodic soils are present locally at shallower depths as well in the mid-eastern portion of the site, where saline soils were encountered only at depths exceeding about $1.5 \mathrm{~m}$.

Emerson Class, Pinhole Class, and Dispersion Per Cent tests also indicated that the soils from the eastern portion of the site (clayey profile) are dispersive and dispersible soils could be encountered locally in the western portion of the site.

\section{SUITABILITY OF SOILS FOR USE IN STRUCTURAL FILL}

Materials encountered during excavations for the proposed lakes and laterals consisted of topsoil and alluvial deposits, comprising clay, sand, and gravel. The topsoil (silt and sandy silt) is very difficult to compact to a state that will attain an acceptable strength (bearing capacity) and resist deformation (settlement characteristics). Furthermore, compaction of silty topsoil is very sensitive to moisture content.

At higher-than-optimum moisture content and under the influence of vibration or traffic loading, the silty topsoil could liquefy and transform more or less into fluid. This could lead to the failure or collapse of structures supported by it. The silty topsoil is also susceptible to surface and internal erosion (piping). Therefore, the topsoil as it exists is unsuitable for use in a structural (engineered) fill. However, if the top 100 $\mathrm{mm}$ to $200 \mathrm{~mm}$ layer of topsoil containing organic materials is stripped and selectively stockpiled for future landscaping purposes, the remaining portion may be used in a structural 
fill. In this process, the following points should be taken into considerations.

- The topsoil can be left in place if the thickness of controlled fill above the topsoil is more than $500 \mathrm{~mm}$. If the controlled fill is less than $500 \mathrm{~mm}$ thick, the topsoil should be excavated partly or entirely and replaced with a structural fill, so that there is at least $500 \mathrm{~mm}$ of structural fill above the topsoil.

- The topsoil may be blended with alluvium available at the site for use in a structural fill, provided the proportion of topsoil in the blended fill does not exceed about 30\% of the total fill volume and the fill placement method does not allow the formation of pockets and layers of topsoil within the blended fill.

- A topsoil-blended fill should be used in the structural fill above the water table only, but is not suitable as subgrade for pavements and (or) building slabs.

- The topsoil in the fill should not be exposed to water. Clayey alluvium (without topsoil) should be used in those parts of fill likely to be exposed to water, such as lakes and drainage channels.

The alluviual deposits, including clay, sand, and gravel, are assessed to be suitable for use in the structural fill.

\section{SUITABILITY OF ALLUVIAL CLAY FOR USE IN LAKE LINING}

As the proposed lakes and laterals are up to $5.0 \mathrm{~m}$ deep, clay, sand, and gravel are exposed at their base and sides (shores), depending on their locations and depths. Highly permeable sand and gravel will be fairly widespread and a relatively impermeable clayey alluvium will be encountered in the eastern portion of the site.

At the completion of development works, water levels in the lakes and laterals will be higher than groundwater levels across the site. Therefore, unless the base and shores of the lakes in sand and gravel are provided with impermeable liners, water loss (seepage) is likely to occur at a considerable rate. The following lining options are considered: (1) Clay lining, (2) Geomembrane lining, (3) Geosynthetic clay liner, and (4) soil-cement lining. Based on the cost and ease of construction methods, clay lining is likely to be the preferred option. The clay with the following properties is suitable for use as an impermeable liner.

- Permeability between $1.0 \times 10^{-7}$ and $1 \times 10^{-9} \mathrm{~m} / \mathrm{s}$

- Particles with $50 \%$ of grains passing through $0.075 \mathrm{~mm}$ sieve

- Low to medium plasticity

- Non-dispersive

- Non-saline

The alluvial clay available at the site satisfies the particle size, plasticity, and permeability requirements but does not meet the dispersive and salinity requirements. The dispersive clay available at the site transforms into practically nondispersive clay when mixed with $3 \%$ of hydrated lime or gypsum. Thus, the clay available at the site may be used as an impervious clay liner when stabilised with $3 \%$ of lime and (or) gypsum. However, the use of lime or gypsum could adversely affect the salinity of the site and hence, on-site clayey soils could not be used in clay liners. Therefore, engineering geological or geotechnical mapping and laboratory tests were carried out to locate external sources of suitable clay. The clay from Agnes Banks, situated about $20 \mathrm{~km}$ north of the site, was found to be suitable for use in clay liners.

\section{IMPACTS AND MANAGEMENT OF SALINE AND SODIC SOILS}

Saline soils are considered a potential hazard for residential and commercial development due to many environmental, economic, and social impacts, such as:

- Agriculture: salinity contributes to significant losses of productivity in agricultural land and can take some land entirely out of production.

- Water quality: salt lowers the quality of water used for rural, domestic, industrial, or urban purposes.

- Public infrastructure and urban households: common impacts attributed to salinity include damage to houses, buildings, roads, highways, and other structures caused by the deterioration of bricks, mortar, concrete, and asphaltic concrete; corrosion of metal (pipes, cables) buried in the ground or set in the structural concrete (reinforcement); shifting or sinking of foundations. A high water table associated with salinity is also attributed to the failure of septic tanks.

- Biodiversity and the environment: rising water table and increasing salinity have serious impacts on native vegetation and consequently on a variety of animal species and habitats. As river salinity rises, the vegetation along the banks could be threatened, resulting in the loss of important wildlife corridors and stream stability.

As the soils from the eastern portion of the proposed development site are saline, the abovementioned environmental, economic, and social impacts should be taken into consideration for the proposed residential and commercial development of the site.

The soils from the eastern portion of the site are also sodic and dispersive, and hence susceptible to erosion and piping. Therefore, residential and commercial development should be carried out with suitable soil management plans to ensure protection and stabilisation of soils susceptible to erosion, and with management and control of sediments during site works. The suggested soil management plans for dealing with saline and sodic soils at the site are the following. 


\section{Lake construction}

Sodic and saline soils excavated for construction of lakes and laterals should be deposited in commercial areas and covered with a minimum of $1.0 \mathrm{~m}$ of non-saline, sandy capping of soil. Non-saline and non-sodic clay should be imported for making clay liners in lakes.

\section{Residential areas}

In the areas where saline soils are encountered, a minimum of $2.0 \mathrm{~m}$ of non-saline sandy capping should be applied. If the proposed structures for the subdivision, including footings, building slabs, road and car park pavements, and underground services, are to be located within a $2.0 \mathrm{~m}$ range of saline soils, the construction methods and materials should be appropriate for moderately aggressive site conditions.

\section{Commercial areas}

The sodic and saline soils deposited in commercial areas should be covered with a minimum of $1.0 \mathrm{~m}$ of non-saline, sandy capping. If proposed structures for the subdivision are to be located within a $1.0 \mathrm{~m}$ range of saline soils, the construction methods and materials should be appropriate for moderately aggressive site conditions. Water management, such as minimising infiltration of storm and irrigation water, should be adopted.

The following recommendations should form part of the soil and water management plan for the proposed residential and commercial development works.

- Erosion and sediment control plans must be developed and implemented by all earthworks contractors, in accordance with the NSW Department of Housing (1988).

- Sediment and erosion controls proposed by the erosion and sediment control plan should be installed prior to the commencement of any construction works.

- Construction activities should not affect the natural flow of groundwater.

- Groundwater recharge is reduced through appropriate land use and land management practices. This is achieved by limiting deep infiltration and through-flow and by enhancing vegetation cover, planting deep-rooted trees, and salt tolerant plants.

- Native and deep-rooted plants should be used to limit soil erosion. Where vegetation cover is not adequate to control erosion, soil resistance to erosion is improved by stabilising dispersive soils with hydrated lime and gypsum. The exact proportions of lime and gypsum should be determined on the basis of laboratory testing.

- In cut and fill batters, a secured turf overlay or shotcrete should be provided to guard against erosion. The construction of a V-drain behind the crest of any slope is recommended to divert water away from the slope.
Construction materials and techniques suitable for a saline environment should be applied.

- Construction materials (concrete, steel, brick, mortar etc) should be suitable for use in a mildly aggressive site.

- Surface water should not be permitted to pond against the walls of any structures. Surrounding paths and ground levels should be sloped to drain water away from the external walls.

- Adequate drainage of down pipes should be provided to divert water from structures.

\section{CONCLUSIONS}

The study revealed (1) relatively saline and dispersive soils cover about $35 \%$ of the site, mainly in the eastern portion; (2) the topsoil can be used as part of engineering fill after special treatment; (3) sandy and clayey alluvial soils are suitable for use as engineering fill; (4) clayey soils are not suitable for use as liners for the proposed lakes and laterals, even after special treatment and importation; (5) importation of suitable clay will be required; and (6) earth works for the proposed development should be in accordance with an appropriate soil management plan dealing with saline, sodic, dispersive, and aggressive soils.

\section{ACKNOWLEDGEMENTS}

The authors would like to thank Ms Pam Kench, Ms Alison Coulson, and Mr Zo Mung of Geotechnique Pty Ltd for their support in the preparation of this paper.

\section{REFERENCES}

Coffey Geosciences Pty Ltd, 1999, Proposed Residential and Commercial Development, corner Cranebrook and Andrews Road, Cranebrook, Falling Head Permeability Test Results, Report No G12033/1-AC, 3 September 1999, 13 p.

Jones, D. C. and Clark, N. R.(Editors), 1987, Geology of the Penrith, Map Scale 1:100,000, Geol. Survey of NSW, Department of Mineral and Energy, 1987.

Department of Land and Water Conservation, 2002, Site Investigation for Urban Salinity, $25 \mathrm{p}$.

Department of Land and Water Conservation, Soil Services, 2002 Sodic Soil Investigation (Revised), Report No SC0991545 dated July $2002,21 \mathrm{p}$.

Geotechnique Pty Ltd, 2003, Proposed Residential and Commercial Development, corner Cranebrook and Andrews Road, Cranebrook, Summery Report for Geotechnical and Groundwater Investigations, Report No 4743/1-AE, 30 September 2003.

NSW Department of Housing, 1988, Managing Urban Stormwater: Soils and Construction, NSW Government, 1988.

Penrith City Council, 2004, Modified Conditions of Lakes Environs Development DAOI/2590 for Corner Andrews and Cranebrook Roads, Cranebrook, 21 June 2004, 48 p.

Robert Carr and Associates Pty Ltd, 2003, Proposed Residential and Commercial Development, corner Cranebrook \& Andrews 


\section{Jworchan et al.}

Road, Cranebrook, Groundwater Modelling, Report No. 1562A- 001/0, 22 July 2003, 27 p.

Bannerman, S. M. and Hazelton, P. A., 1990, Soil Landscape of the Penrith, Map Scale 1:100,00, Soil Conservation Series of NSW, Sydney, 1990.

Standard Australia, 1993, AS1726-1 993 "Geotechnical Site Investigations", 1993, $38 \mathrm{p}$.

Standard Australia, 1995, AS2159-1 995 "Piling — Design and Installation", 1995, $51 \mathrm{p}$.
Sydney Environmental and Soil Laboratory Pty Ltd, 2003 Proposed Residential and Commercial Development, corner Cranebrook \& Andrews Road, Cranebrook, Recommendations on Turf Establishment, 10 December 2003, 56 p.

Taylor, S., 1993, Dryland Salinity, Introductory Extension Noted, Salt Action, Second Edition, Department of Conservation and Land Management. 